\title{
Role of microbial populations in the release of reduced iron to the water column from marine aggregates
}

\author{
S. Balzano ${ }^{1, *}$, P. J. Statham ${ }^{1}$, R. D. Pancost ${ }^{2}$, J. R. Lloyd ${ }^{3}$ \\ ${ }^{1}$ National Oceanography Centre Southampton, Southampton, UK \\ ${ }^{2}$ Organic Geochemistry Unit, University of Bristol, UK \\ ${ }^{3}$ Williamson Research Centre for Molecular Environmental Science and School of Earth, Atmospheric and Environmental \\ Science, University of Manchester, UK
}

\begin{abstract}
The release of dissolved iron from artificial aggregates formed from oxic natural coastal water and senescent phytoplankton material was demonstrated under dark conditions. The rate of release was controlled by the amount of reducible Fe(III) available, and appears to be limited by the competing oxidation of Fe(II). Molecular (16S rRNA gene) analyses showed the bacterial community associated with the aggregates, originating from estuarine water, to be dominated by oxic heterorophs. However, it was possible to culture $\mathrm{NO}_{3}{ }^{-}$and $\mathrm{Fe}(\mathrm{III})$-reducing bacteria from the artificial aggregates, and marine particles incubated with Fe(III) under anaerobic conditions contained microorganisms belonging to the genera Desulfovibrio and Marinobacter, bacteria known to reduce $\mathrm{Fe}(\mathrm{III})$. Whilst the precise mechanism of reduction is not clear, it is evident that marine aggregates can be a source of Fe(II), and thus ultimately iron in other forms, in coastal waters and most probably other natural water systems.
\end{abstract}

KEY WORDS: Biogeochemistry · Phytoplankton · Marine snow · Iron · Particle-associated bacteria · Anaerobic and microaerobic habitats · Bacterial community composition

\section{INTRODUCTION}

High primary production may lead to particle aggregation in pelagic as well as coastal and estuarine waters. The aggregation of particles after a phytoplankton bloom is governed by physical factors such as the particles' shape, size and concentration as well as the velocity shear present in the water column and the stickiness of the particles involved (Simon et al. 2002). Various-sized aggregates may be formed and are usually distinguished as microaggregates $(<0.5 \mathrm{~mm})$ and macroaggregates or marine snow $(>0.5 \mathrm{~mm}$ ) (Simon et al. 2002). The principal constituents of marine aggregates are complex and can include living and dead cells, empty diatom frustules, bacteria, protozoa and zooplankton debris, faecal pellets, macrophyte detritus and clay and silt minerals, with the organic matter comprising a mixture of carbohydrates, proteins, lipids and more complex and refractory organic substances (Simon et al. 2002).

The aggregation and the consequent sedimentation of particles removes nutrients and trace metals from the upper water column, making them unavailable for biological uptake (Shanks \& Trent 1979, Brzezinski et al. 1997). However, intense bacterial metabolism occurs inside the aggregates, leading to the release of dissolved compounds to the surrounding seawater (Azam \& Long 2001) in a form that can again be assimilated by phytoplankton. The degradation of organic matter may thus lead to the release of dissolved elements including nitrogen and phosphorus as well as metals such as iron. The dissolution of iron from sinking particles in subantarctic waters has been reported to be slower than that of carbon and nitrogen (Frew et al. 2006).

Availability of trace metals to plankton depends on their chemical form in seawater. In the oxygenated 
water column, iron is expected to be present as Fe(III) but, due to its low solubility, Fe(III) should exist mainly as poor iron oxides and hydroxides that tend to be scavenged from seawater by settling particles (Sunda 2001). Additionally, it has been reported that $>95 \%$ of iron present in seawater is complexed by organics (Rue \& Bruland 1997). Fe(III) in aqueous systems can also be reduced to $\mathrm{Fe}(\mathrm{II})$ by several microbial mechanisms, including direct electron transfer from the cell surface or via a soluble extracellular mediator or nanowires (Lovley et al. 2004, Gorby et al. 2006). Fe(II) is much more soluble and labile than Fe(III) and forms much weaker organic chelates (Sunda 2001). Any Fe(II) produced in anoxic environments such as sediments and suboxic zones inside large marine flocs is, however, unstable and tends to be oxidised in the oxic water column.

Microbial respiration in aggregates may be important enough to deplete the particles of oxygen, and generate gradients in $\mathrm{pH}$ and solute concentrations (Alldredge \& Cohen 1987, Ploug et al. 1997, Ploug \& Jorgensen 1999) as well as reduced species which are not commonly found in the aerobic water column (Shanks \& Reeder 1993). Oxygen depletion may thus promote the suboxic and anaerobic respiration of organic matter, such as the respiration of $\mathrm{NO}_{3}{ }^{-}$, which has been reported to occur in marine aggregates (Wolgast et al. 1998).

Even though very few investigations have been specifically directed towards anaerobic bacteria, methanogenic, $\mathrm{NO}_{3}{ }^{-}$- and $\mathrm{SO}_{4}{ }^{2-}$-reducing bacteria have all been detected in different natural and artificial aggregates (Bianchi et al. 1992, Bockelmann et al. 2000, Grossart \& Ploug 2000, Tuomainen et al. 2003). However, dissimilatory iron reduction, which has been well described in many environments (Lloyd 2003, Lovley et al. 2004), has never been investigated in marine aggregates. As bacterial reduction of iron oxides requires less reducing conditions than those leading to the formation of $\mathrm{CH}_{4}$ and $\mathrm{HS}^{-}$(Stumm \& Morgan 1993), dissimilatory $\mathrm{Fe}(\mathrm{III})$ reducers are expected to be present in marine aggregates and active under appropriate conditions.

The goals of the present work were to (1) ascertain whether reduced $\mathrm{Fe}(\mathrm{II})$ and $\mathrm{NO}_{2}^{-}$can be released from artificial marine aggregates, and (2) assess the bacter- ial communities present on these artificial flocs, with particular attention given to anaerobic Fe(III)-reducing and $\mathrm{NO}_{3}{ }^{-}$-reducing bacteria.

\section{MATERIALS AND METHODS}

Formation of aggregates and measurement of iron, nutrients and oxygen. Artificial marine aggregates were formed from senescent phytoplankton material of 2 algal species, Thalassiosira weissflogii and Alexandrium tamarense. The strains were cultivated in Guillard's (f/2) marine water enrichment solution (Guillard 1975) in autoclaved seawater as indicated by the supplier (Sigma Aldrich). The f/2 medium contained $\sim 880 \mu \mathrm{mol} \mathrm{l}^{-1}$ of $\mathrm{NO}_{3}{ }^{-}$added as $\mathrm{NaNO}_{3}, 10 \mathrm{nmol} \mathrm{l}^{-1}$ of iron added as $\mathrm{FeCl}_{3} \times 6 \mathrm{H}_{2} \mathrm{O}$ and, to maintain the iron in solution, $10 \mathrm{nmol} \mathrm{l}^{-1}$ of EDTA (Guillard 1975). This iron concentration is very low relative to natural iron concentrations in this coastal system (Fang 1995).

Seawater from Southampton Water that had been previously $5 \mu \mathrm{m}$-filtered and autoclaved was used to dilute the marine water enrichment solution. Cultures were removed from the dark:light cycle during the end of the stationary-state growth phase, when the cells reach their highest concentration and therefore release the highest number of compounds involved in flocculation (Passow \& Alldredge 1995). The stationary-state growth phase was determined after daily observations and cell counting of the cultures using light microscopy. Cultures were then kept in the dark to promote cell degradation and left for $3 \mathrm{~d}$ before the aggregation experiments started. A nearshore seawater sample from Southampton Water (salinity 30) was collected, $10 \mu \mathrm{m}$-filtered to remove large debris, and added to mixed cultures of Thalassiosira weissflogii and Alexandrium tamarense at a 1:9 (seawater:culture) ratio before the aggregation experiment started. In this way, the culture was inoculated with seawater containing a typical near-shore microbial community (Table 1).

Artificial aggregates were also obtained from Southampton Water samples that had been fertilised by adding the marine water enrichment solution as indicated above. Fertilised Southampton Water was

Table 1. Sample abbreviations, type, and origin of cultures

\begin{tabular}{|llll|}
\hline Sample & $\begin{array}{l}\text { Isolation date } \\
\text { (dd/mm/yyy) }\end{array}$ & Sample type & Senescent culture provenance \\
\hline TA1 & $02 / 05 / 2006$ & Aggregates in the medium & Thalassiosira weissflogii and Alexandrium tamarense \\
TA2 & $02 / 05 / 2006$ & Filtered medium (control) & $\begin{array}{l}\text { T. weissflogii and A. tamarense } \\
\text { N1 }\end{array}$ \\
N2 & $03 / 02 / 2006$ & Aggregates in the medium & $\begin{array}{l}\text { Southampton Water } \\
\text { Southampton Water }\end{array}$ \\
\hline
\end{tabular}


incubated on a 12:12 dark:light cycle to promote growth of the natural phytoplankton population (Table 1). The cultured Southampton Water was transferred to the dark room during the stationary-state phase and kept for $3 \mathrm{~d}$ before the aggregation experiments were started.

Flocculation of living and dead cells into aggregates occurred after rotating the polycarbonate cylindrical bottles containing the samples at $15 \mathrm{rpm}$ on a roller table (Shanks \& Edmondson 1989) constructed in the laboratory. After formation, the aggregates with the surrounding $\mathrm{f} / 2$ medium were isolated and transferred into $500 \mathrm{ml}$ polycarbonate flasks using wide-mouth plastic pipettes. Specifically, the aggregates formed from senescent cultures of Thalassiosira weissflogii and Alexandrium tamarense were transferred to Flask TA1, and 0.51 of the medium in which the algal strains had been cultured was $10 \mu \mathrm{m}$-filtered and transferred to Flask TA2. Similarly, the aggregates formed from cultured Southampton Water seawater were transferred to Flask N1, and 0.51 of $10 \mu \mathrm{m}$-filtered medium was transferred to Flask N2. Flasks TA2 and N2 were used as controls. All 4 flasks were only loosely capped to allow air exchange with the solution. Flasks containing aggregates (N1, TA1) as well as the control samples (N2, TA2) were then incubated in the dark at $20^{\circ} \mathrm{C}$ for a period of 1 to $2 \mathrm{wk}$.

Changes in the concentrations of $\mathrm{NO}_{3}{ }^{-}$and $\mathrm{NO}_{2}^{-}$in the flasks over time were followed by periodic subsampling after gentle stirring, followed by determination of $\mathrm{NO}_{2}{ }^{-}$and $\mathrm{NO}_{3}{ }^{-}$using a Burkard autoanalyser (Hansen $\&$ Koroleff 1999). Measurements were made on triplicate samples at each time point.

The concentration of dissolved Fe(II) was measured using the ferrozine method (Viollier et al. 2000): 3 replicate samples of $4 \mathrm{ml}$ were collected from each previously stirred flask. Each was filtered through $0.2 \mu \mathrm{m}$ polycarbonate membranes into cleaned polystyrene test tubes containing $0.5 \mathrm{ml}$ of a $0.1 \mathrm{mM}$ solution of ferrozine (monosodium salt hydrate of 3-(2-pyridyl)-5, 6-diphenyl-1,2,4-triazine-p, $\mathrm{p}^{\prime}$-disulfonic acid). After $\sim 10 \mathrm{~min}$, the absorbance at $562 \mathrm{~nm}$ was measured using a Hitachi U-1500 spectrophotometer. The error bars in Fig. 2 indicate the SD of the concentration of $\mathrm{Fe}(\mathrm{II})$ from the 3 independent replicates.

To prevent trace metal contamination, all plasticware used for the cultivation of phytoplankton, the formation and handling of artificial aggregates, as well as the measurements of dissolved Fe(II) were washed in dilute detergent and then rinsed in a $10 \%(\mathrm{v} / \mathrm{v})$ tracemetal grade $\mathrm{HCl}$ solution before use.

The $\mathrm{pH}$ was measured throughout the experiments and ranged between 6.5 and 7.0; no significant differences in the $\mathrm{pH}$ were found between the flasks containing aggregates and the control flasks.
Microelectrode-based instruments have often been used for the determination of dissolved oxygen in aquatic aggregates (Alldredge \& Cohen 1987, Ploug et al. 1997, Ploug \& Jorgensen 1999). Measurements of oxygen within individual marine aggregates in the present study were made using a Unisense microelectrode (Revsbech 1989) provided with a sensing tip $10 \mu \mathrm{m}$ in diameter. Using a pipette, individual aggregates were gently collected from their flasks and transferred, along with surrounding medium, into a $50 \mathrm{ml}$ glass beaker containing a layer of agar (the agar prevents damage to the microelectrode tip once it has fully penetrated the aggregate). The concentration of oxygen was measured across the particle at steps of $100 \mu \mathrm{m}$, and the electrode signal was logged using a Unisense picoammeter connected to a computer-based data acquisition system. The position of the aggregate surface was determined by slowly advancing the microelectrode towards the aggregate until, under a microscope, it visibly touched the upper surface. Measurements were carried out in a $20^{\circ} \mathrm{C}$ controlled-temperature room and the electrode was calibrated using the same seawater as that used for the experiments; this seawater was turned anoxic by bubbling $\mathrm{N}_{2}$ to set up the zero reading of the electrode and then saturated with oxygen by air bubbling to set up the fully saturated conditions (100\% oxygen). The concentration of oxygen in each solution was then calculated from the percentage of saturation as a function of temperature and salinity according to the method of Revsbech (1989).

Culturing bacteria present in artificial aggregates. The presence in artificial marine aggregates of Fe(III)and $\mathrm{NO}_{3}{ }^{-}$-reducing bacteria was examined using enrichment media to cultivate a variety of microbial functional groups that are able to respire anaerobically. All cultures were inoculated in triplicate with $5 \%$ (v/v) artificial marine aggregates that had been collected after their formation. Cultures were incubated at $20^{\circ} \mathrm{C}$ in the dark to prevent photoreduction. Abiotic controls were obtained by incubating the same medium used to cultivate the aggregates under the same conditions, but without the addition of marine particles. Abiotic controls were not incubated in triplicate.

The base medium utilised for $\mathrm{NO}_{3}{ }^{-}$- and $\mathrm{Fe}(\mathrm{III})$ reducing bacteria was a modification of the recipe of Caccavo et al. (1994) and comprised: $\mathrm{NaHCO}_{3}(2.5 \mathrm{~g}$ $\left.\mathrm{l}^{-1}\right), \mathrm{NH}_{4} \mathrm{Cl}\left(0.25 \mathrm{~g} \mathrm{l}^{-1}\right), \mathrm{NaH}_{2} \mathrm{PO}_{4} \times \mathrm{H}_{2} \mathrm{O}\left(0.6 \mathrm{~g} \mathrm{l}^{-1}\right), \mathrm{KCl}$ $\left(0.1 \mathrm{~g} \mathrm{l}^{-1}\right)$ (Caccavo et al. 1994), vitamin mix (10 $\left.\mathrm{ml} \mathrm{l}^{-1}\right)$ (Balch et al. 1979) and mineral mix $\left(10 \mathrm{ml} \mathrm{l}^{-1}\right)$ (Lovley et al. 1984). The medium was amended with $\mathrm{NaCl}$ $\left(20 \mathrm{~g} \mathrm{l}^{-1}\right)$, and $\mathrm{MgCl}_{2} \times 6 \mathrm{H}_{2} \mathrm{O}\left(3 \mathrm{~g} \mathrm{l}^{-1}\right)$ to emulate marine conditions, and different electron acceptors and donors were added.

Electron donors for the bacterial populations were supplied separately as $15 \mathrm{mmol} \mathrm{l}^{-1}$ acetate or $15 \mathrm{mmol}$ 
$\mathrm{l}^{-1}$ lactate. Terminal electron acceptors were added as $10 \mathrm{mmol} \mathrm{l}^{-1}$ amorphous Fe(III) oxyhydroxide (FeOOH) (Lovley \& Phillips 1986), $10 \mathrm{mmol} \mathrm{l}^{-1} \mathrm{Fe}(\mathrm{III})$-nitriloacetic acid (Fe(III)-NTA) (Lovley \& Woodward 1996) for Fe(III) reducers and $15 \mathrm{mmol} \mathrm{l}^{-1} \mathrm{KNO}_{3}$ for $\mathrm{NO}_{3}{ }^{-}$reducers.

Once prepared, the media were sterilised by $0.22 \mu \mathrm{m}$ filtering or autoclaving, and degassed by bubbling with an 80:20 $\mathrm{N}_{2}: \mathrm{CO}_{2}$ gas mixture for $25 \mathrm{~min}$. The media were then poured into $10 \mathrm{ml}$, sterile, deoxygenated bottles. Samples of artificial marine aggregates were then shaken and a subsample injected into the bottles using sterile syringes. Cultures were then incubated at $20^{\circ} \mathrm{C}$ in the dark. Cultures aimed to identify $\mathrm{Fe}(\mathrm{III})$ reducers were incubated for $2 \mathrm{mo}$, whereas cultures for $\mathrm{NO}_{3}{ }^{-}$reducers were incubated for 1 mo.

$\mathrm{Fe}(\mathrm{III})$ reduction was quantified by the ferrozine colorimetric assay of $\mathrm{Fe}(\mathrm{II})$ after $\mathrm{HCl}$ digestion (Lovley \& Phillips 1986). $\mathrm{NO}_{3}{ }^{-}$reduction was determined by $\left[\mathrm{NO}_{3}{ }^{-}\right]$and $\left[\mathrm{NO}_{2}{ }^{-}\right]$measurements, using a Burkard autoanalyser (Hansen \& Koroleff 1999).

Molecular analysis. Microbial DNA was extracted from the artificial marine snow present in Flask N1, collected $6 \mathrm{~d}$ after the aggregates were formed, rinsed twice in autoclaved seawater to remove the bacterioplankton and frozen at $-20^{\circ} \mathrm{C}$. Microbial DNA was also extracted from 1 enrichment culture for Fe(III) reducers obtained from the artificial marine aggregate; an aliquot of the enrichment culture was collected for molecular analyses during the log phase of the culture growth and frozen at $-20^{\circ} \mathrm{C}$. The log phase of the culture was estimated after the determination of Fe(III) reduction to $\mathrm{Fe}$ (II) in the medium.

Bacterial DNA was extracted using the PowerSoil DNA isolation kit (Mo Bio Laboratories), and bacterial 16S rRNA gene fragments were amplified and analysed as follows.

PCR: 16S rRNA gene amplification was performed on both samples by PCR using primers 8F (Eden et al. 1991) and 519R (Lane et al. 1985) using published methods (Boothman et al. 2006). Amplification of 16S rRNA was performed using Taq DNA polymerase (Sigma Aldrich) following the instructions provided by Sigma Aldrich.

Cloning and Escherichia coli transformation: A TA cloning kit (Invitrogen) was used to isolate individual PCR products from the heterogeneous amplification of 16S rRNA gene fragments. The ligation of PCR products into a TA vector preceded transformation into competent E. coli cells (Mead et al. 1991). Prior to transformation, LB-ampicillin-XGAL agar plates were prepared, containing $30 \mathrm{~g} \mathrm{l}^{-1}$ of Luria-Broth agar media (Fisher Scientific), $50 \mathrm{mg} \mathrm{ml}^{-1}$ of ampicillin (Sigma Aldrich), and $40 \mathrm{mg} \mathrm{ml}^{-1}$ of X-Gel (Bioline). Plates containing transformed cells were incubated at $37^{\circ} \mathrm{C}$, and white colonies were selected for further analysis as they contained plasmids with the required inserted
DNA fragment. The inserted 16S rRNA gene fragments were re-amplified from white colonies using PCR with 25 pmol $\mu^{-1}$ of SCREEN1F and SCREEN1R primers designed against the cloning site in the vector (Boothman et al. 2006).

Restriction fragment length polymorphism (RFLP): The partial 16S rRNA gene fragments were digested with restriction enzymes and analysed by electrophoresis to sort the PCR products into different ribotypes for DNA sequence analysis. All RFLP steps were performed using a mixture of the 2 restriction enzymes EcoRI and MspI (Roche Diagnostics) in a total mix of $10 \mu \mathrm{l}$ containing $8.8 \mu \mathrm{l}$ of PCR product, $1 \mu \mathrm{l}$ buffer A (Roche Diagnostics) and $0.1 \mu \mathrm{l}$ of each enzyme. Reactions were incubated at $37^{\circ} \mathrm{C}$ for $\sim 16 \mathrm{~h}$, and results were checked in a $3 \%$ agarose gel (Brettschneider 1998).

DNA sequencing and phylogenetic analysis: The DNA sequence of each ribotype was performed using an ABI Prism BigDye Terminator Cycle Sequencing Kit in combination with an ABI Prism 877 Integrated Thermal Cycler and ABI Prism 377DNA Sequencer (Perkin Elmer Applied Biosystems). Sequencing results were analysed using CHROMAS software, and BLAST searches (http://blast.ncbi.nlm.nih.gov/BLAST.cgi), were performed at both gene and protein level. Alignments and phylogenetic relationships were inferred by the neighbour-joining method using CLC free workbench (www.clcbio.com).

\section{RESULTS}

$$
\mathrm{NO}_{3}{ }^{-} \text {and } \mathrm{NO}_{2}{ }^{-}
$$

The concentration of $\mathrm{NO}_{3}{ }^{-}$and $\mathrm{NO}_{2}{ }^{-}$over time in the 2 flasks containing artificial marine aggregates and in the controls are shown in Fig. 1. $\mathrm{NO}_{3}{ }^{-}$concentrations

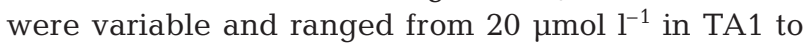
$220 \mathrm{\mu mol} \mathrm{l}^{-1}$ in the control (N2). Even though the initial concentration of $\mathrm{NO}_{3}{ }^{-}$was similar in all samples, the concentrations of $\mathrm{NO}_{3}{ }^{-}$in both flasks containing aggregates (TA1 and N1) at the end of the experiments were lower than in the respective seawater controls (TA2 and N2). Samples prepared from Southampton Water in Flasks $\mathrm{N} 1$ and $\mathrm{N} 2$ contained more $\mathrm{NO}_{3}{ }^{-}$than the ones deriving from controlled phytoplankton cultures (TA1 and TA2) at the end of the experiment.

The concentration of $\mathrm{NO}_{2}{ }^{-}$ranged from $1.5 \mu \mathrm{mol} \mathrm{l}^{-1}$

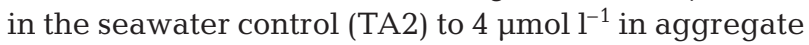
Flask N1, and increased over time in both flasks containing aggregates (TA1 and N1) (Fig. 1). In N1, it increased by $\sim 50 \%$ over $7 \mathrm{~d}$. In the controls, TA2 and $\mathrm{N} 2$, the concentration of $\mathrm{NO}_{2}{ }^{-}$was constant or decreased slightly (Fig. 1). 

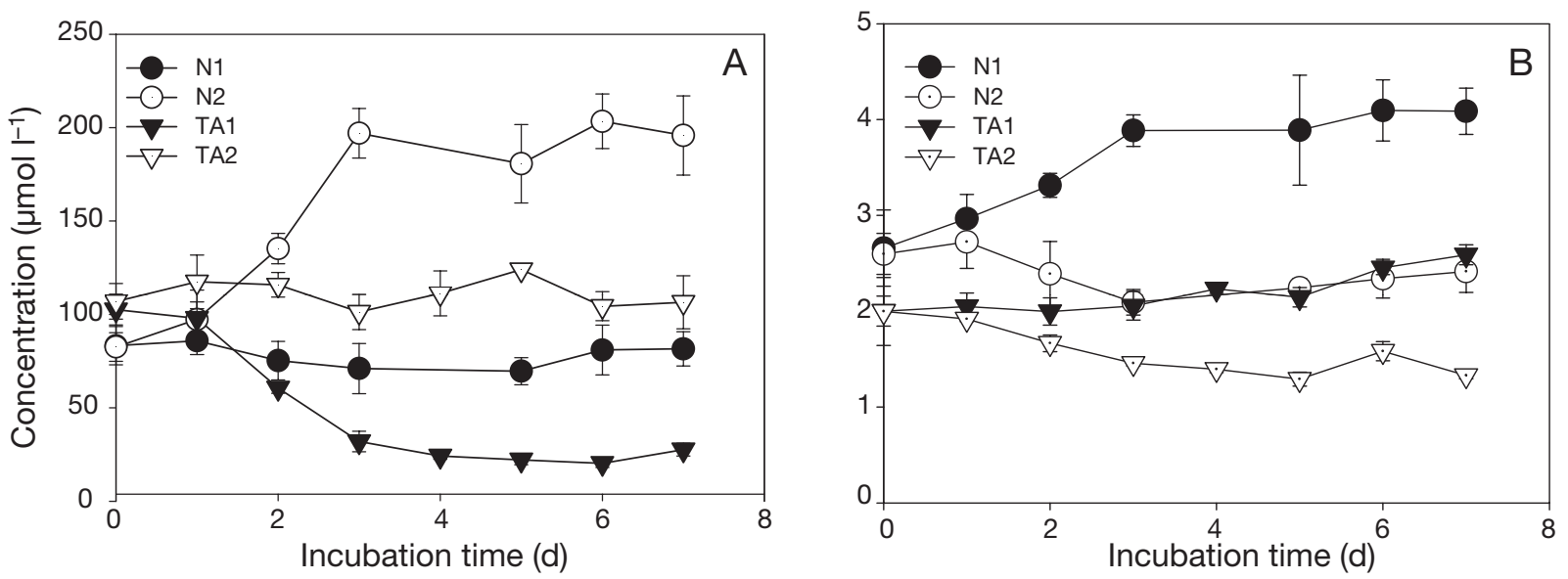

Fig. 1. Concentration of (A) $\mathrm{NO}_{3}{ }^{-}$and (B) $\mathrm{NO}_{2}{ }^{-}$in the samples containing aggregates and in the seawater controls. N1: aggregates formed from Southampton Water cultured to enhance the natural phytoplankton populations; N2: $5 \mu \mathrm{m}$-filtered cultured Southampton Water (control); TA1: aggregates formed from a mixed phytoplankton culture of Thalassiosira weissflogii and Alexandrium tamarense; TA2: $5 \mu \mathrm{m}$-filtered culture of $T$. weissflogii and A. tamarense (control)

\section{Dissolved Fe(II)}

The concentration of dissolved Fe(II) in the aqueous environment surrounding marine aggregates ranged from $0.1 \mu \mathrm{mol} \mathrm{l}^{-1}$ in $\mathrm{N} 1$ and TA1 at the beginning of the experiments to $0.7 \mu \mathrm{mol} \mathrm{l}^{-1}$ in TA1 after $8 \mathrm{~d}$ and $0.55 \mathrm{in}$ $\mathrm{N} 1$ after $11 \mathrm{~d}$ (Fig. 2). Thus, the concentration of dissolved Fe(II) increased over time in Flasks TA1 and N1 by 500 and $300 \%$, respectively. After $11 \mathrm{~d}$ of incubation, the concentration of Fe(II) in aggregate Flask N1 had decreased substantially (Fig. 2). The concentration of dissolved Fe(II) in aggregate Flask TA1 was not measured after Day 8. The concentration of Fe(II) in the seawater controls was, on the other hand, more or less constant (Fig. 2).

\section{Oxygen saturation}

The concentration of dissolved oxygen, measured in 2 individual aggregates, was found to drop from $215 \mu_{\mathrm{mol} \mathrm{l}}^{-1}$ in the surrounding seawater to $100 \mu \mathrm{mol}$ $\mathrm{l}^{-1}$ in the centre of the aggregates, but anoxia was not detected in any aggregate (Fig. 3). At the base of the particle, the oxygen concentration did not fully return to background, probably reflecting the restricted diffusion of oxygen through the agar on which the particle was sitting.

\section{Culturing of $\mathrm{Fe}(\mathrm{III})-$ and $\mathrm{NO}_{3}{ }^{-}$-reducing bacteria}

Bacteria capable of respiring $\mathrm{Fe}(\mathrm{III})$ and $\mathrm{NO}_{3}{ }^{-}$under anaerobic conditions were found to be present in the artificial marine aggregates. Reduction of Fe(III)-NTA and $\mathrm{FeOOH}$ occurred in aggregates collected from Flasks N1 and TA1 and cultured anaerobically (Table 2). In particular, 1 of the replicates of Flask N1, incubated with lactate as the electron donor and Fe(III)-NTA as the electron acceptor, reduced all added Fe(III) (10 mM) over 2 mo (Table 2). After 2 mo following the first incubation, an aliquot $(200 \mu \mathrm{l})$ of this culture was inoculated into new sterile medium, and after another 2 mo incubation, the added $10 \mathrm{mmol} \mathrm{l}^{-1}$ Fe(III)-NTA was completely reduced to Fe(II) again. However, incubations containing insoluble FeOOH as the electron acceptor and lactate as the electron donor showed a lower production of Fe(II) (Table 2). The concentrations of $\mathrm{Fe}(\mathrm{II})$ in the abiotic controls were low compared to the samples and ranged from 1.1 to $1.3 \mathrm{mmol} \mathrm{l}^{-1}$ (Table 2).

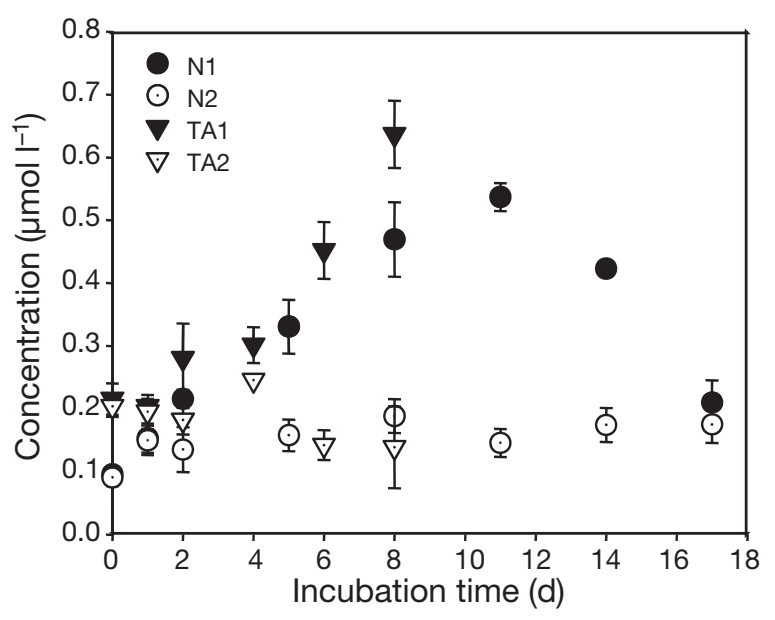

Fig. 2. Concentration of dissolved Fe(II) in the samples. See Fig. 1 for sample abbreviations 


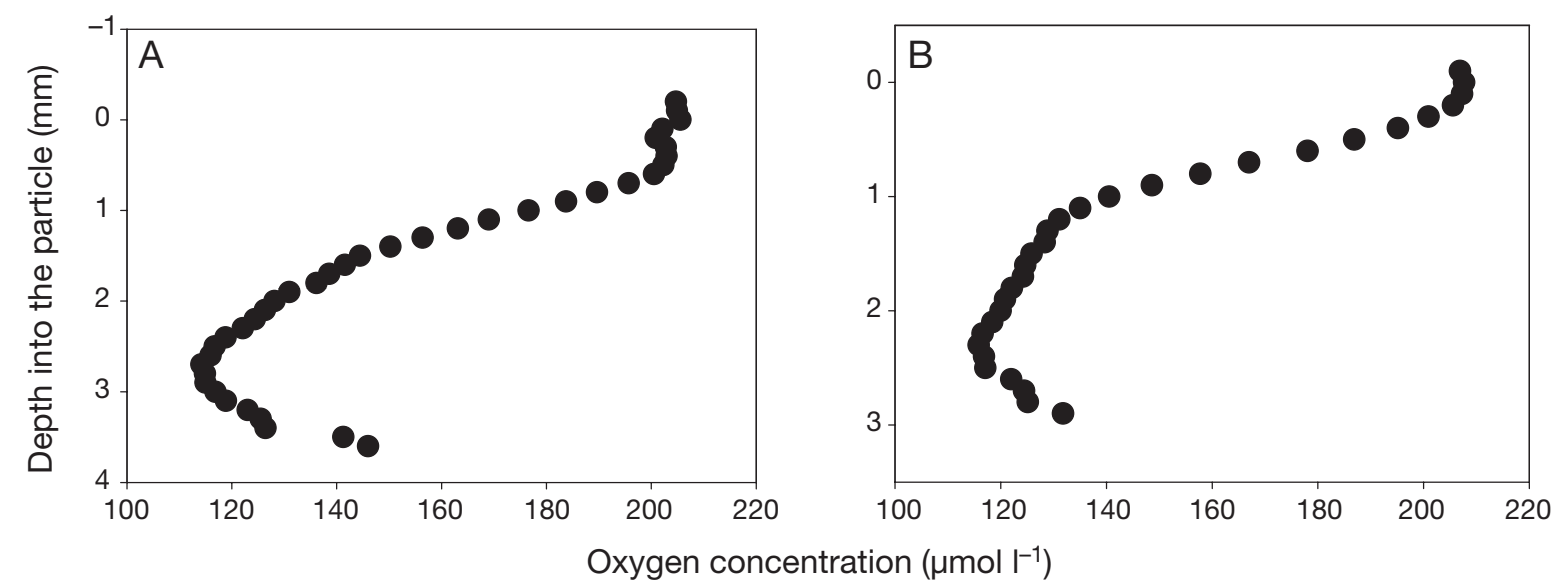

Fig. 3. Profile of dissolved oxygen concentration across individual aggregates isolated from (A) Flask N1 and (B) Flask TA1

Analyses of $\mathrm{NO}_{3}{ }^{-}$/lactate enrichment cultures confirmed the presence and activity of $\mathrm{NO}_{3}{ }^{-}$-reducing microorganisms, with a strong loss of $\mathrm{NO}_{3}{ }^{-}$but little accumulation of the denitrification intermediate $\mathrm{NO}_{2}{ }^{-}$ (Fig. 4). Aggregates were initially incubated with $15 \mathrm{mmol} \mathrm{l}^{-1} \mathrm{NaNO}_{3}$ as electron acceptor. After $30 \mathrm{~d}$ of incubation, the cultures contained $0.1 \mathrm{mmol} \mathrm{l}^{-1}$ of $\mathrm{NO}_{2}^{-}$ and no measurable $\mathrm{NO}_{3}{ }^{-}$(Fig. 4). $\mathrm{NO}_{3}{ }^{-}$reduction was not observed in $\mathrm{NO}_{3}{ }^{-}$/acetate incubations that, after $30 \mathrm{~d}$ of incubation, contained $12.8 \pm 0.7 \mathrm{mmol} \mathrm{l}^{-1}$ of $\mathrm{NO}_{3}{ }^{-}$and no measurable $\mathrm{NO}_{2}{ }^{-}$. The concentration of $\mathrm{NO}_{3}{ }^{-}$in the abiotic controls was $13.9 \pm 0.2 \mathrm{mmol} \mathrm{l}^{-1}$, whereas $\mathrm{NO}_{2}^{-}$was not detected.
1993, Bockelmann et al. 2000, Brachvogel et al. 2001, Simon et al. 2002, Selje \& Simon 2003). The most abundant organisms identified in the clone library were related to strains SIMO-738, BT60MF2BD12, GMDsbC3, P8-GEN-18 and SIMO-110 (Table 3). Most of the organisms identified from molecular analysis of the aggregates N1 were uncultured, except Colwelia sp., Formosa sp., Legionella sp., Orientalimare eburneum, and Roseobacter litoralis, which were present as low fractions of the total, ranging from 1 to $3 \%$ of the clone library (Table 3). No known Fe(III)-reducing bacteria were detected using these broad specificity primers. In addition to direct molecular analyses of DNA from aggregates, Fe(III)-reducing bacteria

\section{Molecular analysis}

The diversity of $16 \mathrm{~S}$ rRNA gene sequences recovered from aggregates and 1 selected enrichment culture was examined by RFLP sorting followed by gene analyses. Amplification of 16S rRNA gene fragments with primers $8 \mathrm{~F}$ and 519R from aggregates present in Flask N1 revealed a comparatively simple microbial community with 21 different RFLP types from 150 different clones (Table 3). Of the 21 different RFLP types, the most highly represented were affiliated with Cyano- bacteria (24\% of the clone library), Bacteroidetes (27\%), and $\gamma$-Proteobacteria $(13 \%) ; \alpha$-Proteobacteria were also present (Table 3). Data are in partial agreement with previous studies on microbial colonisation of aggregates (DeLong et al.
Table 2. Concentration of dissolved Fe(II) in the anaerobic enrichments of aggregates in Flasks N1 and TA1 incubated with different electron acceptors (EA) and donors (ED) and in the abiotic controls. Values are means \pm SD from 3 replicate cultures for the anaerobic cultures of aggregates, and means \pm SD of measurements taken on 1 single incubated bottle for the abiotic control

\begin{tabular}{|lcc|}
\hline Flask & Substrate (EA/ED) & Fe(II) concentration $(\mathrm{mM})$ \\
\hline Abiotic control & Acetate/Fe(III)-NTA & $1.25 \pm 0.06$ \\
Abiotic control & Acetate/FeOOH & $1.15 \pm 0.02$ \\
Abiotic control & Lactate/Fe(III)-NTA & $1.21 \pm 0.05$ \\
Abiotic control & Lactate/FeOOH & $1.33 \pm 0.26$ \\
TA1 & Acetate/Fe(III)-NTA & $3.28 \pm 0.08$ \\
TA1 & Acetate/FeOOH & $3.10 \pm 0.15$ \\
TA1 & Lactate/Fe-NTA & $2.97 \pm 1.07$ \\
TA1 & Lactate/FeOOH & $1.91 \pm 0.15$ \\
N1 & Acetate/Fe(III)-NTA & $1.52 \pm 0.05$ \\
N1 & Acetate/FeOOH & $1.64 \pm 0.06$ \\
N1 & Lactate/Fe(III)-NTA & $1.81 \pm 0.49^{\text {a }}$ \\
N1 & Lactate/Fe(III)-NTA & $9.85^{\mathrm{b}}$ \\
N1 & Lactate/FeOOH & $1.26 \pm 0.27$ \\
aOnly 2 replicates & & \\
bThird replicate (used also for molecular analysis) \\
\hline
\end{tabular}




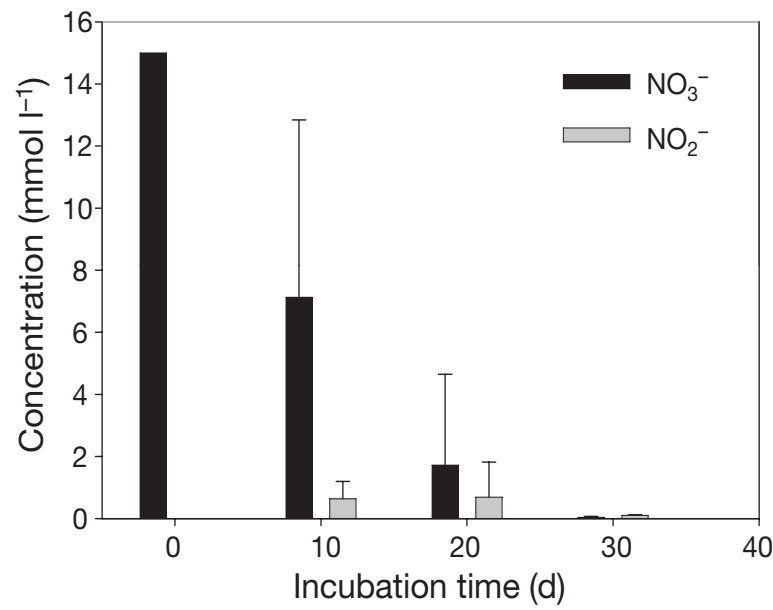

Fig. 4. Depletion of $\mathrm{NO}_{3}{ }^{-}$in the artificial aggregates $\mathrm{N} 1$ anaerobically incubated with lactate as electron donor and $\mathrm{NaNO}_{3}$ as electron acceptor

were also enriched using appropriate growth media. Amplification of $16 \mathrm{~S}$ rRNA gene fragments from enrichments using lactate as the electron donor and Fe(III)-NTA as the electron acceptor, performed using primers $8 \mathrm{~F}$ and $519 \mathrm{R}$, revealed the presence of 3 different RFLP types; 2 of these represented $93 \%$ of the clone library and contained genes affiliated with the genus Marinobacter, whereas the third was most closely related to Desulfovibrio sp., Clone NA302 (Table 4).

\section{DISCUSSION}

The large increase of Fe(II) and slight increase in $\mathrm{NO}_{2}^{-}$over time, measured in Flasks N1 and TA1 containing aggregates prepared from natural and defined phytoplankton cultures, respectively (Figs. 1 $\& 2$ ), are associated with decreasing or relatively constant $\mathrm{NO}_{3}^{-}$concentrations (Fig. 1). This behaviour suggests (1) the occurrence of $\mathrm{Fe}$ (III) reduction to $\mathrm{Fe}(\mathrm{II})$ and (2) $\mathrm{NO}_{2}{ }^{-}$production due to $\mathrm{NO}_{3}{ }^{-}$reduction and/or $\mathrm{NO}_{2}{ }^{-}$release during nitrification. As there was very little change in $\mathrm{NO}_{2}^{-}$and $\mathrm{Fe}(\mathrm{II})$ in the seawater control Flasks N2 and TA2 (Figs. 1 \& 2), the reductions occurring in Flasks N1 and TA1 appear to be related to processes inside the aggregates as oxygen became depleted due to intense bacterial respiration (see Fig. 3). The rates of reduction processes producing $\mathrm{Fe}(\mathrm{II})$ and $\mathrm{NO}_{2}{ }^{-}$must be significantly greater than their oxidation rates in the oxic regions of aggregates and in the surrounding seawater in order for measurable concentrations of these reduced species to be present.

\section{$\mathrm{NO}_{3}{ }^{-}$and $\mathrm{NO}_{2}{ }^{-}$}

The residual $\mathrm{NO}_{3}{ }^{-}$in aggregate incubation solutions was much lower than in the initial f/2 solutions, which indicates significant uptake into phytoplankton biomass prior to aggregate formation. The solutions of sta-

Table 3. Taxonomic affiliation of 16S rRNA ribotypes identified in aggregates collected from Flask N1 after analysis of the partial 16S rRNA gene fragment. NCBI: National Center for Biotechnology Information

\begin{tabular}{|c|c|c|c|c|c|}
\hline Closest matching microorganism & $\begin{array}{c}\text { NCBI accession } \\
\text { number }\end{array}$ & Group & Identities & $\%$ matches & $\begin{array}{l}\text { Percentage } \\
\text { present }\end{array}$ \\
\hline Uncultured clone SIMO-738 & AY712275 & Cyanobacteria & $432 / 448$ & 96 & 16 \\
\hline Uncultured clone BT60MF2BD12 & AF365593 & Unknown & $428 / 432$ & 99 & 12 \\
\hline Clone GMDsbC3 & AY162097 & Bacteroidetes & $470 / 503$ & 93 & 12 \\
\hline Uncultured clone P8-GEN-18 & AY361930 & Unknown & $448 / 472$ & 94 & 9 \\
\hline Uncultured clone PI_4z6c & AY580687 & Bacteroidetes & $265 / 290$ & 91 & 6 \\
\hline Uncultured clone SIMO-1100 & AY710540 & Cyanobacteria & $301 / 329$ & 91 & 6 \\
\hline Uncultured clone CD2E6 & AY038472 & Unknown & $435 / 449$ & 96 & 5 \\
\hline Uncultured clone SCF_4984 & AJ630720 & Bacteroidetes & $479 / 493$ & 97 & 5 \\
\hline Uncultured clone SC1-14 & DQ289918 & $\gamma$-Proteobacteria & $357 / 404$ & 88 & 3 \\
\hline Legionella sp. OUB41 & AB058918 & $\gamma$-Proteobacteria & $401 / 446$ & 89 & 3 \\
\hline Formosa sp. 18III/A01/079 & AY612758 & Bacteroidetes & $474 / 502$ & 94 & 3 \\
\hline Uncultured clone CD13H5 & AF441870 & $\alpha$-Proteobacteria & $384 / 446$ & 86 & 3 \\
\hline Uncultured clone SBET_5159 & AJ630710 & $\gamma$-Proteobacteria & $511 / 526$ & 97 & 3 \\
\hline Uncultured clone Belgica2005/10-140-11 & DQ351790 & $\gamma$-Proteobacteria & $318 / 352$ & 90 & 3 \\
\hline Uncultured clone SIMO-1415 & AY710855 & Cyanobacteria & $440 / 449$ & 97 & 1 \\
\hline Uncultured clone SIMO-1334 & AY710774 & Cyanobacteria & $428 / 444$ & 96 & 1 \\
\hline Uncultured clone JH12_C91 & AY568926 & Unknown & $320 / 356$ & 89 & 1 \\
\hline Colwellia sp. 'Egg clone D45' & AF034927 & $\gamma$-Proteobacteria & $351 / 363$ & 96 & 1 \\
\hline Orientalimare eburneum strain SW-277 & DQ667965 & $\alpha$-Proteobacteria & $265 / 269$ & 98 & 1 \\
\hline Uncultured Flavobacteria bacterium clone SIMO-582 & $2 \quad A Y 712119$ & Bacteroidetes & $417 / 502$ & 83 & 1 \\
\hline Roseobacter litoralis Och 149 (ATCC 49566) & X78312 & $\alpha$-Proteobacteria & $441 / 451$ & 97 & 1 \\
\hline
\end{tabular}


Table 4. Taxonomic affiliation of the 16S rRNA ribotypes identified in the anaerobic enrichment of aggregates collected from Flask N1 incubated with lactate as the electron donor and Fe(III)-NTA as the electron acceptor. NCBI: National Center for Biotechnology Information

\begin{tabular}{|c|c|c|c|c|c|}
\hline $\begin{array}{l}\text { Closest matching } \\
\text { microorganism }\end{array}$ & $\begin{array}{c}\text { NCBI accession } \\
\text { number }\end{array}$ & Class & Identities & $\%$ matches & $\begin{array}{l}\text { Percentage } \\
\text { present }\end{array}$ \\
\hline Marinobacter aquaeolei OC-11 & AY669171 & $\gamma$-Proteobacteria & $462 / 485$ & 95 & 90 \\
\hline Desulfovibrio sp. NA302 & AJ866944 & $\delta$-Proteobacteria & $490 / 493$ & 99.4 & 7 \\
\hline Marinobacter sp. CAB & U61848 & $\gamma$-Proteobacteria & $499 / 508$ & 98.2 & 2 \\
\hline
\end{tabular}

tionary-phase phytoplankton used were expected to contain a range of nitrogen species including dissolved organic nitrogen (DON). As aggregates were incubated in the dark for all of the experiments, the net continued $\mathrm{NO}_{3}{ }^{-}$removal observed, especially in Flask TA1 (Fig. 1), must have been caused by non-photosynthetic microbial processes. The aggregates in Flask N1 (Fig. 1) presumably took up as much $\mathrm{NO}_{3}{ }^{-}$as they produced from oxidation of DON. The most important observation is the net production of the reduced form of nitrogen, $\mathrm{NO}_{2}^{-}$, in TA1 and $\mathrm{N} 1$, relative to the controls.

The $\mathrm{NO}_{3}{ }^{-}$production observed in control Flask N2 (Fig. 1) most probably reflects release of $\mathrm{NO}_{3}{ }^{-}$from oxidation of DON and decomposition of small phytoplankton debris passing through the $5 \mu \mathrm{m}$ filter. An analogous increase in the concentration of $\mathrm{NO}_{3}{ }^{-}$was not observed in control Flask TA2, reflecting a different origin of biomass and balance of bacterial uptake and recycling of $\mathrm{NO}_{3}^{-}$.

$\mathrm{NO}_{2}^{-}$production in Flasks $\mathrm{N} 1$ and TA1 was not stoichiometrically equivalent to the $\mathrm{NO}_{3}{ }^{-}$losses (Fig. 1), probably because part of the $\mathrm{NO}_{2}{ }^{-}$was further reduced and part of the $\mathrm{NO}_{3}{ }^{-}$was taken up by organisms rather than reduced by dissimilatory processes. However, the presence of $\mathrm{NO}_{2}{ }^{-}$indicates that active $\mathrm{NO}_{3}{ }^{-}$reduction or nitrification occurred.

The presence of other reduced species such as $\mathrm{CH}_{4}$ and $\mathrm{HS}^{-}$in marine particles has been reported in previous studies (Shanks \& Reeder 1993, Karl \& Tilbrook 1994). $\mathrm{CH}_{4}$ and $\mathrm{HS}^{-}$are expected to be produced from the reduction of $\mathrm{CO}_{2}$ and $\mathrm{SO}_{4}{ }^{2-}$ ions, respectively, which are electron acceptors yielding less energy compared to $\mathrm{NO}_{3}^{-}, \mathrm{NO}_{2}^{-}, \mathrm{Mn}(\mathrm{IV})$ and $\mathrm{Fe}(\mathrm{III})$ reduction (Stumm \& Morgan 1993). Thus, only very low values of $\mathrm{pE}$ make the production of $\mathrm{CH}_{4}$ and $\mathrm{HS}^{-}$possible. However, the absence of anoxic microzones, as suggested by oxygen electrode profiles in Flasks N1 and TA1 (Fig. 3), is in agreement with some previous studies on oxygen concentrations in marine aggregates in oxic water columns (Alldredge \& Cohen 1987, Ploug \& Jorgensen 1999) and suggests that detectable anoxic microzones are unlikely to be present in natural or artificial aquatic aggregates.

\section{Iron reduction}

The f/2 medium (Guillard 1975) made in coastal seawater contained $10 \mathrm{nmol} \mathrm{l}^{-1}$ of EDTA and a similar concentration of Fe(III). However, these concentrations are 1 order of magnitude lower than the concentration of Fe(II) measured in the control samples, and 60-fold less than the highest values seen in the incubation experiment. Therefore, the EDTA and iron introduced should not have significantly influenced the observed results, and reduced iron in solution must have been produced by the aggregates. The Fe(II) was measured using the ferrozine method, for which any dissolved Fe(III) present does not significantly affect the measurement (Viollier et al. 2000). At the high concentration of ferrozine used $\left(0.1 \mathrm{mmol} \mathrm{l}^{-1}\right)$, and given the high stability constant for Fe(II) with the reagent, it is expected that any organic complexes of Fe(II) were also determined.

Significant concentrations (average $160 \mathrm{nmol} \mathrm{l}^{-1}$ ) of dissolved total iron (Head 1971, Fang 1995) have been observed in the water column in Southampton Water, from where the water used in the present experiments came. Measurements of particulate iron were not carried out for the present work, but artificial aggregates obtained following the same method as described here contained 20 (range: 9 to 27) $\mu \mathrm{mol}$ of iron per gram of suspended particulate matter. The containers (2 1) used to form aggregates contained 10 to $50 \mathrm{mg} \mathrm{l}^{-1}$ of suspended organic matter $(>0.2 \mu \mathrm{m})$ and were expected to contain between 0.2 and $1.0 \mu \mathrm{mol} \mathrm{l^{-1 }}$ of particulate iron. The aggregates were transferred after their formation to smaller $(0.5 \mathrm{l})$ flasks in order to increase the aggregates:seawater ratio, thus increasing the amount of particulate iron available for reduction per litre.

Iron in oxygenated natural waters and at high $\mathrm{pH}$ should be present as Fe(III) (Millero et al. 1987) and the oxidation process for Fe(II) is a function of the oxygen concentration as well as the seawater $\mathrm{pH}$ (Millero et al. 1987). The $\mathrm{pH}$ in the samples ranged from 6.5 to 7 without showing any obvious variation over time or between aggregate samples and controls, and for samples at this pH and in contact with air, the concentration of any dissolved iron in seawater above equilib- 
rium concentrations should decrease over time, as dissolved Fe(III) produced from Fe(II) oxidation tends to be scavenged by particles and precipitate as particulate Fe(III) (Sunda 2001). One reason for the very high concentrations of dissolved Fe(II) in the present study was the presence of organic ligands that may have inhibited oxidation. Interactions of $\mathrm{Fe}(\mathrm{II})$ with dissolved organic matter has been suggested to slow Fe(II) oxidation in the Southern Ocean (Croot et al. 2001, 2007, 2008, Moffett 2001) and Indian Ocean hydrothermal plumes (Statham et al. 2005). Such ligand-Fe(II) complexes would also explain the relatively high background of Fe(II) ( 150 nmol $\left.\mathrm{l}^{-1}\right)$ in the controls in the present experiments, where high concentrations of dissolved organic matter from the cultures were expected.

The increase in the concentration of dissolved Fe(II) in the samples containing aggregates indicates the net reduction of the Fe(III) present inside the flocs. No Fe(III) material was added to the aggregates and so the release of Fe(II) must have been from the reduction of natural Fe(III) phases present within the aggregates, as no change in Fe(II) was observed in the seawater controls without aggregates. The relatively high concentrations of $\mathrm{Fe}$ (II) in the samples were 1 to 2 orders of magnitude higher than those observed in natural coastal waters (Fig. 2), which reflects the small volume of seawater $(0.5 \mathrm{l})$ used in the experiment and the absence of large-scale dilution occuring in natural waters. The gradual decline in Fe(II) concentration towards the end of the experiment (Fig. 2) most probably reflects the exhaustion of reducible Fe(III) species in the aggregates and the predominance of oxic removal of reduced $\mathrm{Fe}(\mathrm{II})$. The reduction process described here can be an important natural process that adds to the pool of Fe(II) in the surrounding water and that effectively recycles the Fe(III) in the aggregates.

\section{Reducing processes in aerobic environments}

The release of reduced compounds from aggregates in oxic waters, observed in the present and previous works (Shanks \& Reeder 1993, Karl \& Tilbrook 1994), appears contradictory to the absence of anoxic microzones detectable by an oxygen microelectrode with a $10 \mu \mathrm{m}$ sensing tip as used in the present study. One possible mechanism is the reduction of the mentioned solutes inside anoxic microenvironments. However, these environments would need to be strongly anoxic and abundant enough to reduce measurable amounts of all the solutes mentioned in the present study as well as those in the literature. Anoxic microzones could be generated as a consequence of an intense aerobic respiration coupled with a low porosity that would inhibit the penetration of oxygen in comparison to the rest of the aggregate. An anoxic or suboxic microenvironment can be maintained as long as the oxygen diffusion rate from the surrounding environment does not exceed the overall oxygen consumption rate in that microenvironment. The oxygen diffusion rate is proportional to the surface area through which it diffuses, whereas the oxygen consumption rate is proportional to the amount of organic matter being degraded and therefore to the volume of that microenvironment. The smaller in size an environment is, the less likely it is to become anoxic.

Assuming that solutes diffuse through the aggregates as quickly as they do through seawater, a microregion $10 \mu \mathrm{m}$ thick (diameter) should consume $100 \mu \mathrm{mol} \mathrm{O}_{2} \mathrm{~mm}^{-3} \mathrm{~h}^{-1}$ to conserve its anoxic conditions (Ploug et al. 1997). To maintain this rate of consumption of oxygen from the surrounding environment, the microbial communities present in marine aggregates would need to continuously respire enormous amounts of organic matter. The chemical diffusion of solutes within aggregates has been hypothesised to be slower than in seawater (Shanks \& Reeder 1993, Alldredge 2000) due to the presence of substances such as transparent exopolymer particles (TEP), which are abundant in marine aggregates (Alldredge et al. 1993). However, the solute diffusion rate within marine aggregates has been reported recently to range between 0.85 and $0.95 \times$ the value in seawater (Ploug \& Passow 2007); in that work, the sensing tip used for measuring diffusivity was rather wide $(100 \mu \mathrm{m}$ diameter), resulting in a tip section area of $7850 \mu^{2}, 100 \times$ greater than the section of the oxygen microelectrode tip used in our experiments (10 $\mu \mathrm{m}$ diameter). Given the large area of the diffusivity sensor, microzones with lower diffusivity (e.g. particles surrounded by TEP) might have been present without impacting the overall diffusivity through the zones of the particles investigated. Microregions, present but not abundant in the aggregates, may thus still be present and have a diffusivity significantly lower than in the surrounding seawater.

As marine aggregates are very heterogeneous, the oxygen consumption within them may also be very variable: low where the organic matter is refractory and intense where fresh labile organic matter is available. Low-diffusion substances such as TEP could act as gas barriers, limiting the diffusion of oxygen inside the aggregates and allowing the formation of suboxic or anoxic subregions; this may occur especially where the organic matter is labile and the oxygen is therefore quickly respired by microbial communities.

The mechanisms of Fe(III) reduction in the environment remain heavily debated and can include direct reduction by cytochromes on the outer membrane of Gram- 
negative Fe(III)-reducing bacteria (Lovley et al. 2004), or by secreted electron shuttles (von Canstein et al. 2008) or nanowires protruding from the cell surface (Reguera et al. 2005, Gorby et al. 2006). However Fe(III) reduction proceeds, it is most probable that under low oxygen conditions, only the Fe(III) particles close to the microbial cell are reduced, releasing Fe(II) into the local environment, and in turn out of the aggregates by diffusion.

The production of reduced species has been considered to occur only under anaerobic conditions (Stumm \& Morgan 1993). However, under low oxygen conditions, Shewanella oneidensis was shown to simultaneously reduce $\mathrm{Fe}(\mathrm{III}), \mathrm{NO}_{3}{ }^{-}$and $\mathrm{NO}_{2}{ }^{-}$(DiChristina 1992). $\mathrm{Fe}(\mathrm{II})$ has also been found under suboxic conditions in sediment porewaters (Sell \& Morse 2006) as well as in the oxygen minimum zone in the water column where $\mathrm{NO}_{2}{ }^{-}$was also found (Moffett et al. 2007). The simultaneous respiration of $\mathrm{NO}_{3}{ }^{-}$and $\mathrm{O}_{2}$ has also been shown to occur within both phytodetritus (Wolgast et al. 1998) and coastal sediment (Brandes \& Devol 1995). Diatoms and Cyanobacteria have been shown to produce superoxides and extra-cellular enzymes able to reduce Fe(III) to $\mathrm{Fe}(\mathrm{II})$ in aerobic waters (Maldonado \& Price 1999, 2000, Shaked et al. 2002, 2004, 2005, Kustka et al. 2005, Salmon et al. 2006), although the impact of these processes on the overall iron dissolution appears to be more relevant under iron-depleted conditions.

The reduction of $\mathrm{Fe}(\mathrm{III})$ and $\mathrm{NO}_{3}{ }^{-}$in the presence of oxygen, even if not thermodynamically favoured, thus seems to be an important process in the water column as well as in sediments.

\section{Bacterial populations in aggregates}

Aggregates analysed in the present study were formed in samples from Southampton Water whose salinity was about 30 , and the bacterial community found in Flask N1 is consistent with previous studies on bacterial colonisation of marine aggregates (DeLong et al. 1993, Bockelmann et al. 2000, Brachvogel et al. 2001, Simon et al. 2002, Selje \& Simon 2003). Even though the samples had been stored for $3 \mathrm{~d}$ in the dark before the aggregation experiments and aggregates were collected for analysis $6 \mathrm{~d}$ after their formation, still in the dark, Cyanobacteria were detected. The 16S rRNA gene PCR does not distinguish between viable and inactive bacteria; however, as Cyanobacteria are photosynthetic microorganisms, even though they were present, they were not expected to be active in the aggregates. The bacterial community identified by PCR amplification and sequencing of 16S rRNA genes appeared to be dominated by aerobes, with obligate anaerobic microorganisms only a small component of the total microbial community. This is consistent with the presence of oxygen throughout the aggregates in both the TA1 and N1 experiments. However, a low proportion of anaerobes does not mean that they are not active or important in biogeochemical cycling. Indeed, cultures developed from the artificial aggregates readily demonstrated the presence of viable Fe(III)-reducing bacteria.

\section{Bacteria potentially involved in iron reduction}

The 3 different RFLP types found in the lactate/ Fe(III)NTA enrichment culture do not match with any well-described organisms known to respire Fe(III). As anaerobic cultures of aggregates produced much more Fe(II) than abiotic controls under Fe(III)-enriched conditions, (Table 2), the microbial role in the reduction of $\mathrm{Fe}(\mathrm{III})$ is evident. However, caution is required in comparing the cultured bacterial communities to those in the aggregate decomposition experiments. First, the concentration of $\mathrm{Fe}(\mathrm{III})$ used to culture the Fe(III)-reducing bacteria present in aggregates was $10 \mathrm{mmol} \mathrm{l}^{-1}, 5$ orders of magnitude higher than the concentration of dissolved iron measured in Southampton Water. Second, the medium used to culture the aggregates was completely deoxygenated with a mixture of $\mathrm{N}_{2}$ and $\mathrm{CO}_{2}$ being bubbled through the medium for 20 min before sealing the bottles (the lower control concentrations of Fe(II) reflects the chemical reduction of $\mathrm{Fe}(\mathrm{III})$ under these anoxic conditions). Marine aggregates very rarely become completely anoxic. Thus, it is not clear which bacterial strains described in Table 4 are viable in lower substrate concentrations; nonetheless, the release of Fe(II) and consumption of $\mathrm{NO}_{3}{ }^{-}$during the experiments do indicate the presence of $\mathrm{NO}_{3}{ }^{-}$- and $\mathrm{Fe}(\mathrm{III})$-reducing bacteria in aggregates, and these bacteria might be wholly or partially represented by the populations observed in the corresponding cultures.

The microbial role in the reduction of Fe(III) could be ascribed to Desulfovibrio sp.: recent work showed that 2 strains of Desulfovibrio sp. can also grow using Fe(III) compounds as the sole electron acceptors ( $\mathrm{Li}$ et al. 2006). The other 2 clones found in the lactate/Fe-NTA enrichment are related to Marinobacter aquaeolei and Marinobacter sp. (Table 4). Organisms belonging to the genus Marinobacter have been shown in the literature to be able to oxidise iron (Edwards et al. 2003) under hypoxic or anoxic conditions, by either oxygen or $\mathrm{NO}_{3}{ }^{-}$. Recent studies have also suggested that members of the genus Marinobacter also have the potential to respire Fe(III) with lactate supplied as the electron donor (Handley et al. (in press).

The data shown in Fig. 4 highlight the initial presence of $\mathrm{NO}_{3}{ }^{-}$and $\mathrm{NO}_{2}{ }^{-}$reducers in aggregates that were incubated for several days. Whether the initial 
pool of $\mathrm{NO}_{3}{ }^{-}$in the incubations was transformed to $\mathrm{NH}_{4}{ }^{+}$(via dissimilatory nitrate reduction to ammonia, DNRA) or gaseous compounds of nitrogen such as $\mathrm{N}_{2}$, $\mathrm{NO}$ and $\mathrm{N}_{2} \mathrm{O}$ (denitrification sensu strictu) (Zumft 1997) is not clear at this stage. Cyanobacterial aggregates in the Baltic Sea were found to contain denitrification genes, but denitrification activity was found to be negligible (Tuomainen et al. 2003). The results shown in Fig. 4 suggest that the reduction of $\mathrm{NO}_{3}{ }^{-}$in artificial marine aggregates is significant. Algal aggregates are different from cyanobacterial ones and do not appear to contain many nitrogen fixers (DeLong et al. 1993, Bockelmann et al. 2000, Brachvogel et al. 2001, Simon et al. 2002, Selje \& Simon 2003), so $\mathrm{NO}_{3}{ }^{-}$ reduction is likely to be a significant process. The $\mathrm{NO}_{3}{ }^{-}$-reducing microorganisms were cultivated in a medium containing a concentration of $\mathrm{NO}_{3}{ }^{-}(15 \mathrm{mM})$ that was 2 orders of magnitude higher than that in coastal waters. However, the data shown in Fig. 4 indicate the presence of viable $\mathrm{NO}_{3}{ }^{-}$reducers in aggregates, although it is not known whether the same process would have occurred at lower substrate concentrations. Bacteria able to perform a wide variety of anaerobic or suboxic redox processes are thus present in artificial marine aggregates formed in estuarine water that contained its natural bacterial community. However, whilst bacterial reduction was shown to occur in the present study, which used enrichment media with high substrate concentrations, the bacterial process under natural conditions that leads to release of Fe(II) has yet to be fully elucidated.

\section{CONCLUSIONS}

The results of the present study indicate that marine aggregates can release reduced $\mathrm{Fe}(\mathrm{II})$, produce $\mathrm{NO}_{2}{ }^{-}$ and host a range of viable bacteria that can metabolise under different oxygen concentrations and appear to be involved in these processes. Whilst the amounts of $\mathrm{NO}_{3}{ }^{-}$and $\mathrm{Fe}(\mathrm{III})$ used to culture the dissimilatory $\mathrm{NO}_{3}{ }^{-}-$ and Fe(III)-reducing bacteria present in aggregates are 2 to 5 orders of magnitude higher than in natural waters, the presence of these viable organisms and their capacity to reduce $\mathrm{Fe}(\mathrm{III})$ and $\mathrm{NO}_{3}{ }^{-}$were clearly shown. The release of $\mathrm{Fe}(\mathrm{II})$ indicates active reduction of Fe(III), and thus the presence of zones in the aggregates with a $\mathrm{pE}$ lower than -5 (Stumm \& Morgan 1993) to allow the reduction of Fe(III). This reduction could occur in anoxic microzones (not detected by the oxygen sensor because they are smaller than its tip diameter) presumably in close proximity to the cell surface of bacteria. Alternatively, some bacteria seem able to reduce $\mathrm{Fe}(\mathrm{III})$ even in the presence of low oxygen concentrations. In either scenario, diffusion of oxygen to the reduction site must be inhibited, or oxygen depleted, to prevent the rapid re-oxidation of any reduced iron. An important role may also be played by organic compounds, released by particles or organisms, that are able to complex Fe(II) and thus retard its oxidation to Fe(III).

In the present study, some release of $\mathrm{NO}_{2}^{-}$was evident, either through $\mathrm{NO}_{3}{ }^{-}$reduction $\left(\mathrm{NO}_{3}{ }^{-}\right.$reducers were present in aggregates) or through nitrification of DON. The $\mathrm{NO}_{3}{ }^{-}$depletion from the environment surrounding the aggregates was anticipated to be caused by bacterial uptake.

The present study supports earlier work showing that reduced species are released to the water column, and adds Fe(II) to the list of thermodynamically unstable compounds that can be released from marine aggregates. Whilst the present and previous studies have detected anaerobic microorganisms in aggregates (Bianchi et al. 1992, Bockelmann et al. 2000, Simon et al. 2002), their activities and mode of operation have yet to be fully investigated.

Acknowledgements. This work was supported by a 'Marie Curie Actions' Early Stage Training programme (BIOTRACS, FP6-514262) award. The work was carried out at the National Oceanography Centre, Southampton (NOCS) and at the School of Earth, Atmospheric and Environmental Science (SEAES) of the University of Manchester. We thank P. Gooddy for laboratory assistance on nutrient analyses at NOCS, S. P. Marques Monteiro and C. Boothman for assistance in molecular analyses at SEAES and K. Handley for assistance in the cultivation of anaerobic bacteria at SEAES.

\section{LITERATURE CITED}

Alldredge AL (2000) Interstitial dissolved organic carbon (DOC) concentrations within sinking marine aggregates and their potential contribution to carbon flux. Limnol Oceanogr 45:1245-1253

Alldredge AL, Cohen Y (1987) Can microscale chemical patches persist in the sea? Microelectrode study of marine snow, fecal pellets. Science 235:689-691

Alldredge AL, Passow U, Logan BE (1993) The abundance and significance of a class of large, transparent organic particles in the ocean. Deep-Sea Res I 40:1131-1140

Azam F, Long RA (2001) Oceanography: sea snow microcosms. Nature 414:495-498

Balch WE, Fox GE, Magrum LJ, Woese CR, Wolfe RS (1979) Methanogens: Reevaluation of a unique biological group. Microbiol Rev 43:260-296

> Bianchi M, Marty D, Teyssie JL, Fowler SW (1992) Strictly aerobic and anaerobic-bacteria associated with sinking particulate matter and zooplankton fecal pellets. Mar Ecol Prog Ser 88:55-60

> Bockelmann U, Manz W, Neu TR, Szewzyk U (2000) Characterization of the microbial community of lotic organic aggregates ('river snow') in the Elbe River of Germany by cultivation and molecular methods. FEMS Microbiol Ecol 33:157-170

> Boothman C, Hockin S, Holmes DE, Gadd GM, Lloyd JR (2006) Molecular analysis of a sulphate-reducing consor- 
tium used to treat metal-containing effluents. Biometals 19:601-609

Brachvogel T, Schweitzer B, Simon M (2001) Dynamics and bacterial colonization of microaggregates in a large mesotrophic lake. Aquat Microb Ecol 26:23-35

Brandes J, Devol A (1995) Simultaneous $\mathrm{NO}_{3}{ }^{-}$and oxygen respiration in coastal sediments: evidence for discrete diagenesis. J Mar Res 53:771-797

Brettschneider R (1998) RFLP analysis. In: Karp A, Isaac P, Ingram D (eds) Molecular tools for screening biodiversity: plants and animals. Chapman \& Hall, London, p 83-95

Brzezinski MA, Alldredge AL, O'Bryan LM (1997) Silica cycling within marine snow. Limnol Oceanogr 42: 1706-1713

Caccavo F Jr, Lonergan DJ, Lovley DR, Davis M, Stolz JF, McInerney MJ (1994) Geobacter sulfurreducens sp. nov., a hydrogen- and acetate-oxidizing dissimilatory metalreducing microorganism. Appl Environ Microbiol 60: 3752-3759

Croot PL, Bowie AR, Frew RD, Maldonado MT and others (2001) Retention of dissolved iron and Fe-II in an iron induced Southern Ocean phytoplankton bloom. Geophys Res Lett 28:3425-3428

Croot PL, Frew RD, Sander S, Hunter KA and others (2007) Physical mixing effects on iron biogeochemical cycling: FeCycle experiment. J Geophys Res Oceans 112, CO6015, doi: 10.1029/2006JC003748

Croot PL, Bluhm K, Schlosser C, Streu P, Breitbarth E, Frew R, Van Ardelan M (2008) Regeneration of Fe(II) during EIFeX and SOFeX. Geophys Res Lett 35:L19606

Cummings DE, Snoeyenbos-West OL, Newby DT, Niggemyer AM, Lovley DR, Achenbach LA, Rosenzweig RF (2003) Diversity of Geobacteraceae species inhabiting metal-polluted freshwater lake sediments ascertained by $16 \mathrm{~S}$ rDNA analyses. Microb Ecol 46:257-269

DeLong EF, Franks DG, Alldredge AL (1993) Phylogenetic diversity of aggregate-attached vs free-living marine bacterial assemblages. Limnol Oceanogr 38:924-934

DiChristina TJ (1992) Effects of nitrate and nitrite on dissimilatory iron reduction by Shewanella-putrefaciens 200. J Bacteriol 174:1891-1896

Eden PA, Schmidt TM, Blakemore RP, Pace NR (1991) Phylogenetic analysis of Aquaspirillum magnetotacticum using polymerase chain reaction-amplified 16S rRNA-specific DNA. Int J Syst Bacteriol 41:324-325

Edwards KJ, Rogers DR, Wirsen CO, McCollom TM (2003) Isolation and characterization of novel psychrophilic, neutrophilic, Fe-oxidizing, chemolithoautotrophic alpha- and gamma-proteobacteria from the deep sea. Appl Environ Microbiol 69:2906-2913

Fang TH (1995) Studies of the behaviour of trace metals during mixing in some estuaries of the Solent region. $\mathrm{PhD}$ thesis, University of Southampton

Frew RD, Hutchins DA, Nodder S, Sanudo-Wilhelmy S, Tovar-Sanchez A, Leblanc K, Hare CE, Boyd PW (2006) Particulate iron dynamics during FeCycle in subantarctic waters southeast of New Zealand. Global Biogeochem Cycles 20, GB1593, doi: 10.1029/2005GB002558

Gorby YA, Yanina S, McLean JS, Rosso KM and others (2006) Electrically conductive bacterial nanowires produced by Shewanella oneidensis strain MR-1 and other microorganisms. Proc Natl Acad Sci USA 103:11358-11363

Grossart HP, Ploug H (2000) Bacterial production and growth efficiencies: direct measurements on riverine aggregates. Limnol Oceanogr 45:436-445

Guillard R (1975) Culture of phytoplankton for feeding marine invertebrates. Plenum Press, New York
Handley K, Héry M, Lloyd J (in press) Marinobacter santoriniensis sp. nov., a novel arsenate-respiring and arsenite-oxidizing bacterium isolated from hydrothermal sediment at Santorini, Greece. Int J Syst Evol Microbiol

Hansen H, Koroleff F (2007) Determination of nutrients. In: Grasshoff K, Kremling K, Ehrhardt M (eds) Methods of seawater analysis, 3rd edn. Wiley-VCH, Weinheim, p 159-228

Head PC (1971) Observations on concentration of iron in sea water, with particular reference to Southampton water. J Mar Biol Assoc UK 51:891-903

Karl DM, Tilbrook BD (1994) Production and transport of methane in oceanic particulate organic matter. Nature 368:732-734

Kustka AB, Shaked Y, Milligan AJ, King DW, Morel FMM (2005) Extracellular production of superoxide by marine diatoms: contrasting effects on iron redox chemistry and bioavailability. Limnol Oceanogr 50:1172-1180

- Lane DJ, Pace B, Olsen GJ, Stahl DA, Sogin ML, Pace NR (1985) Rapid determination of $16 \mathrm{~S}$ ribosomal RNA sequences for phylogenetic analyses. Proc Natl Acad Sci USA 82:6955-6959

> Li YL, Vali H, Yang J, Phelps TJ, Zhang CL (2006) Reduction of iron oxides enhanced by a sulfate-reducing bacterium and biogenic $\mathrm{H}_{2} \mathrm{~S}$. Geomicrobiol J 23:103-117

Lloyd J (2003) Microbial reduction of metals and radionuclides. FEMS Microbiol Rev 27:411-425

Lovley DR, Phillips EJP (1986) Organic matter mineralization with reduction of $\mathrm{Fe}(\mathrm{III})$ in anaerobic sediments. Appl Environ Microbiol 51:683-689

> Lovley DR, Woodward JC (1996) Mechanisms for chelator stimulation of microbial Fe(III)-oxide reduction. Chem Geol 132:19-24

> Lovley DR, Greening RC, Ferry JG (1984) Rapidly growing rumen methanogenic organism that synthesizes coenzyme $\mathrm{M}$ and has a high affinity for formate. Appl Environ Microbiol 48:81-87

Lovley D, Holmes D, Nevin K (2004) Dissimilatory Fe(III) and Mn(IV) reduction. Adv Microb Physiol 49:219-286

Maldonado MT, Price NM (1999) Utilization of iron bound to strong organic ligands by plankton communities in the subarctic Pacific Ocean. Deep-Sea Res II 46: 2447-2473

Maldonado MT, Price NM (2000) $\mathrm{NO}_{3}{ }^{-}$regulation of iron reduction and transport by Fe-limited Thalassiosira oceanica. Limnol Oceanogr 45:814-826

Mead DA, Pey NK, Herrnstadt C, Marcil RA, Smith LM (1991) A universal method for the direct cloning of PCR amplified nucleic acid. Biotechnology (NY) 9:657-663

Millero FJ, Sotolongo S, Izaguirre M (1987) The oxidation kinetics of $\mathrm{Fe}(\mathrm{II})$ in seawater. Geochim Cosmochim Acta 51:793-801

Moffett JW (2001) Transformations among different forms of iron in the ocean. In: Turner DR, Hunter KA (eds) The biogeochemistry of iron in seawater. John Wiley \& Sons, Chichester, p 343-372

> Moffett JW, Goeffert TJ, Naqvi SWA (2007) Reduced iron associated with secondary $\mathrm{NO}_{2}^{-}$maxima in the Arabian Sea. Deep-Sea Res I 54:1341-1349

- Passow U, Alldredge AL (1995) Aggregation of a diatom bloom in a mesocosm: the role of transparent exopolymer particles (TEP). Deep-Sea Res II 42:99-109

Ploug H, Jorgensen BB (1999) A net-jet flow system for mass transfer and microsensor studies of sinking aggregates. Mar Ecol Prog Ser 176:279-290

Ploug H, Passow U (2007) Direct measurement of diffusivity within diatom aggregates containing transparent exopolymer particles. Limnol Oceanogr 52:1-6 
Ploug H, Kuehl M, Buchholz-Cleven B, Jørgensen BB (1997) Anoxic aggregates: an ephemeral phenomenon in the pelagic environment? Aquat Microb Ecol 13:285-294

Reguera G, McCarthy KD, Mehta T, Nicoll JS, Tuominen MT, Lovley DR (2005) Extracellular electron transfer via microbial nanowires. Nature 435:1098-1101

Revsbech NP (1989) An oxygen microsensor with a guard cathode. Limnol Oceanogr 34:474-478

Rue EL, Bruland KW (1997) The role of organic complexation on ambient iron chemistry in the equatorial Pacific Ocean and the response of a mesoscale iron addition experiment. Limnol Oceanogr 42:901-910

Salmon TP, Rose AL, Neilan BA, Waite TD (2006) The FeL model of iron acquisition: nondissociative reduction of ferric complexes in the marine environment. Limnol Oceanogr 51:1744-1754

Selje N, Simon M (2003) Composition and dynamics of particle-associated and free-living bacterial communities in the Weser estuary, Germany. Aquat Microb Ecol 30:221-237

Sell K, Morse J (2006) Dissolved $\mathrm{Fe}^{2+}$ and $\Sigma \mathrm{H}_{2} \mathrm{~S}$ behavior in sediments seasonally overlain by hypoxic-to-anoxic waters as determined by CSV microelectrodes. Aquat Geochem 12:179-198

Shaked Y, Erel Y, Sukenik A (2002) The biogeochemistry and speciation of iron in the Sea of Galilee (Lake Kinneret). Geochim Cosmochim Acta 66, Suppl 1. Conference Abstract A700

Shaked Y, Erel Y, Sukenik A (2004) The biogeochemical cycle of iron and associated elements in Lake Kinneret. Geochim Cosmochim Acta 68:1439-1451

Shaked Y, Kustka AB, Morel FMM (2005) A general kinetic model for iron acquisition by eukaryotic phytoplankton. Limnol Oceanogr 50:872-882

Shanks AL, Edmondson EW (1989) Laboratory-made artificial marine snow: a biological model of the real thing. Mar Biol 101:463-470

Editorial responsibility: Hugh Ducklow, Woods Hole, Massachusetts, USA
Shanks A, Reeder ML (1993) Reducing microzones and sulphide production in marine snow. Mar Ecol Prog Ser 96:43-47

Shanks AL, Trent JD (1979) Marine snow - microscale nutrient patches. Limnol Oceanogr 24:850-854

- Simon M, Grossart HP, Schweitzer B, Ploug H (2002) Microbial ecology of organic aggregates in aquatic ecosystems. Aquat Microb Ecol 28:175-211

Statham PJ, German CR, Connelly DP (2005) Iron (II) distribution and oxidation kinetics in hydrothermal plumes at the Kairei and Edmond vent sites, Indian Ocean. Earth Planet Sci Lett 236:588-596

Stumm W, Morgan JJ (1993) Aquatic chemistry: chemical equilibria and rates in natural waters, 3rd edn. John Wiley \& Sons, New York

Sunda W (2001) Bioavailability and bioaccumulation of iron in the sea. In: Turner DR, Hunter KA (eds) The biogeochemistry of iron in seawater. Wiley, New York, p 41-84

Tuomainen JM, Hietanen S, Kuparinen J, Martikainen PJ, Servomaa K (2003) Baltic Sea cyanobacterial bloom contains denitrification and nitrification genes, but has negligible denitrification activity. FEMS Microbiol Ecol 45:83-96

Viollier E, Inglett PW, Hunter K, Roychoudhury AN, Van Cappellen P (2000) The ferrozine method revisited: Fe(II)/ $\mathrm{Fe}(\mathrm{III})$ determination in natural waters. Appl Geochem 15:785-790

von Canstein H, Ogawa J, Shimizu S, Lloyd JR (2008) Secretion of flavins by Shewanella species and their role in extracellular electron transfer. Appl Environ Microbiol 74:615-623

> Wolgast DM, Carlucci AF, Bauer JE (1998) $\mathrm{NO}_{3}{ }^{-}$respiration associated with detrital aggregates in aerobic bottom waters of the abyssal NE Pacific. Deep-Sea Res II 45:881-892

Zumft WG (1997) Cell biology and molecular basis of denitrification. Microbiol Mol Biol Rev 61:533-582

Submitted: June 10, 2008; Accepted: December 24, 2008 Proofs received from author(s): February 24, 2009 